\title{
DEVELOPING BIM-ASSISTED AS-BUILT SCHEDULE MANAGEMENT SYSTEM FOR GENERAL CONTRACTORS
}

\author{
Hui-Ping TSERNG, Shih-Ping HO, Shu-Hui JAN \\ Department of Civil Engineering, National Taiwan University, No. 1 Roosevelt Rd, Sec. 4, Taipei, Taiwan
}

Received 20 Jun 2013; accepted 10 Sep 2013

\begin{abstract}
Construction project control attempts to obtain real-time as-built schedule information and to eliminate project delays by effectively enhancing dynamic schedule control and management. Suitable platforms for enhancing an as-built schedule visually during the construction phase are necessary and important for general contractors. As the application of building information modeling (BIM) becomes more common, schedule management integrated with the BIM approach becomes essential to enhance visual construction management implementation for the general contractor during the construction phase. To enhance visualization of the updated as-built schedule for the general contractor, this study presents a novel system called the Construction BIM-assisted Schedule Management (ConBIM-SM) system for general contractors in Taiwan. The primary purpose of this study is to develop a web ConBIM-SM system for the general contractor to enhance visual as-built schedule information sharing and efficiency in tracking construction as-built schedule. Finally, the ConBIM-SM system is applied to a case study of a commerce building project in Taiwan to verify its efficacy and demonstrate its effectiveness during the construction phase. The advantages of the ConBIM-SM system lie in improved project control and management efficiency for general contractors, and in providing BIM-assisted as-built schedule tracking and management, to access the most current as-built schedule information through a web browser. The case study results show that the ConBIM-SM system is an effective visual as-built schedule management platform integrated with the BIM approach for general contractors in a construction project.
\end{abstract}

Keywords: building information modelling (BIM), construction schedule management, web-based system, as-built schedule management, BIM schedule updating mechanism.

Reference to this paper should be made as follows: Tserng, H.-P.; Ho, S.-P.; Jan, S.-H. 2014. Developing BIM-assisted asbuilt schedule management system for general contractors, Journal of Civil Engineering and Management 20(1): 47-58. http://dx.doi.org/10.3846/13923730.2013.851112

\section{Introduction}

An original schedule can be updated frequently, particularly as a construction project becomes larger and more complex. A general contractor typically requires access to as-built schedule information to control and manage construction projects. Updated as-built schedule management (SM) is essential to control and manage construction projects, particularly because it enhances communication and coordination among project participants. Promptly sharing the updated as-built schedule with other participants helps them make compatible decisions, which helps to minimize possible disputes. Therefore, updated as-built schedule monitoring and control among project participants should be necessary and important to the general contractor. Until recently, on-site progress data collection has been mainly paper-based. This method has been reported as one of the major problems that causes project delays and cost overruns (Davidson, Skibniewski 1995). Manual methods, which are impractically slow and do not always achieve the desired result, require a great deal of time and energy (Navon 2007; Trupp et al. 2004; Hegazy, Abdel-Monem 2012). Consequently, collection of as-built schedules from project participants is ineffective, thus reducing efficiency and resulting in a lack of as-built schedule information. This process ultimately results in confusion. With the advent of Internet technology, web-based as-built schedule information management solutions have facilitated information distribution and sharing among project participants. Utilization of web technology enhances the sharing of as-built schedule information in construction projects and has recently become increasingly important due to the ease with which information can be shared through web solutions.

In Taiwan, there currently exists a multitude of practice problems regarding updating an as-built schedule at the jobsite in Taiwan (Lin 2009). One of those problems is obtaining an accurate position and location from textbased illustrations of a traditional schedule. Building information modeling (BIM) is a new industry term re-

Corresponding author: Shu-Hui Jan

E-mail: d94521007@ntu.edu.tw 
ferring to parametric 3D computer-aided design (CAD) technologies and processes in the AEC industry (Taylor, Bernstein 2009). During the construction phase, effectively tracking and managing as-built schedule information integrated with BIM-assisted illustration in construction reduces mistakes. Effective BIM-assisted as-built schedule information sharing allows project engineers to identify a current as-built schedule and make accurate decisions in the visual environment. Despite many studies and discussions in academic and practical literature regarding the simulation of $4 \mathrm{D}$ approaches (3D computer model + time), few studies on the practical updating of as-built schedules, integrated with the BIM approach during the construction phase, have emerged.

The proposed approach is to enhance onsite updating of the as-built schedule integrated with BIM models for visual schedule management. To advance this notion, the study presents a novel approach called the Construction BIM-assisted Schedule Management (ConBIM-SM) system for general contractors to enhance as-built schedule information sharing and tracking. Furthermore, this study demonstrates that the proposed system is efficient in information sharing and enhances as-built schedule information implantation through the ConBIM-SM system. The ConBIM-SM system retains the as-planned and asbuilt schedule information in a digital format, and facilitates easy updates and shares updating as-built schedule information in the web environment. By using the ConBIM-SM system, project and BIM engineers can obtain an overview of the previous and current as-built schedule updated information for a given project. Furthermore, project engineers can access and utilize the most recent updates to the as-built models during the construction phase. The changes and problems with the as-built models can be made available to each project engineer via the markup-enabled as-built schedule. This research is a pilot study to apply the ConBIM-SM system for SM work during a building project in Taiwan, and to analyze and discuss the entire BIM SM work. Many problems and limitations will surface when onsite updating of an as-built schedule is implemented. The main contribution of the study is to explore the experience of tracking and managing BIM-assisted as-built scheduling during the construction phase.

\section{Literature review}

To facilitate construction planning, visualization technology has become widespread (Liston et al. 1998). BIM is a new industry term that refers to $3 \mathrm{D}$ illustration technology that incorporates parameters and processes related to the AEC industry (Taylor, Bernstein 2009). Almost ten years ago, BIM was introduced as an environment in which any information on 3D entity models could be stored and retrieved throughout a project's life cycle (Tse et al. 2005). A BIM model is a digital visual representation of all of a building's physical characteristics and relevant information on its life cycle (Manning, Messner
2008). In prior research, many different definitions of BIM have been proposed. BIM contains precise digital geometric measurements and data to support a project's design, procurement, fabrication, and construction activities to describe CAD (Eastman et al. 2011). BIM's main feature is that the complete model, with all of its parts, is saved in a single file. Moreover, any changes made to the model automatically affect any related data and drawings accordingly. BIM modelling allows users to create and update project-related documents automatically, and data on the building are attached to the model's elements (Eastman et al. 2011). BIM helps construction planners to make important decisions by providing a visual of the details of the project in the future (Chau et al. 2004). BIM is a tool that allows for efficient applications of the management and execution of construction projects.

There are many core adoption, advantages, barriers, limitations, and frameworks for the use of BIM in supporting decisions and improving processes throughout the life cycle of a project (Shen, Issa 2010; Manning, Messner 2008; Becerik-Gerber, Rice 2010; Underwood, Isikdag 2010; $\mathrm{Gu}$, London 2010; Eastman et al. 2011; Arayici et al. 2011; Jung, Joo 2011; Barlish, Sullivan 2012; Porwal, Hewage 2013). The characteristics that are beneficial to the construction phase include a reduction in necessary rework, increased customer satisfaction as a result of the visual model, more productive phasing and scheduling, more efficient and timely construction management with a swift form of communication, accurate estimation of cost, and a clearer visual for safety testing (Hardin 2009; Matta, Kam 2010; Eastman et al. 2011; Elbeltagi, Dawood 2011; Azhar 2011; Zhou et al. 2013; Hartmann et al. 2012).

Over the past few years, the focus of many research efforts has been the use of information technology (IT) to enhance automation aided by the BIM approach. Redmond et al. (2012) utilized cloud computing as a platform on which to integrate the BIM applications known as "Cloud BIM". This integration enhanced the BIM user's experience in making important decisions regarding design in various disciplines. Ren et al. (2012) proposed a framework in which BIM could be used to integrate applications for cost estimation and quantity takeoff with e-commerce solutions for procurement of materials and evaluation of supplier performance. $\mathrm{Li}$ et al. (2012) integrated virtual prototyping and fourdimensional simulation to assist construction planners in testing the sequence of construction activities when mobile cranes are involved. To manage construction defects, Park et al. (2013) presented a conceptual system framework in which BIM was integrated with ontology and augmented reality (AR). Davies and Harty (2013) developed tools based on BIM to enable site workers to access information on the design, record work quality, and update records of progress on-site on their personal tablets or computers. Martins and Monteiro (2013) created a BIM-based system to automatically check proce- 
dure codes for water distribution systems. Irizarry et al. (2013) integrated the BIM approach with geographic information systems (GIS) to track the status of a supply chain and to provide warning signals that would result in successful delivery of materials. Zhang et al. (2013) integrated BIM with an automated safety-check platform to forewarn construction engineers and managers of potential accidents related to falls before the start of any actual construction.

Since the early 1990's, an increasing amount of attention has been paid to the idea of four-dimensional computer-aided design (4D CAD) for planning construction projects. Commercially available 4D CAD applications are becoming more widespread and easily accessible, and this technology enables the construction planner to produce more detailed, concise, and rigorous schedules. These commercially available packages typically focus on the use of 4D CAD simulations for the purpose of visualization (Heesom, Mahdjoubi 2004). A great deal of previous research has concentrated on applying 4D CAD to the use of construction schedules. Russell et al. (2009) were able to visualize strategies for construction of a high-rise building through the use of linear scheduling and 4D CAD. Kim et al. (2011) presented a case study analyzing construction of a cable-stayed bridge, as well as modelling this process with a $4 \mathrm{D}$ graphic simulation. Zhang and $\mathrm{Hu}$ (2011) used a 4D structural information model to resolve conflicts and alleviate safety issues throughout construction. Hu and Zhang (2011) developed a BIM-assisted 4D-based system for the same purpose. Li et al. (2012) utilized a 4D simulation and virtual prototyping to help construction planners to examine the feasibility of mobile cranes in the construction process. Chavada et al. (2012) integrated critical path method and BIM to provide real-time management and rehearsal of activity execution workspaces. Zhou et al. (2013) used $4 \mathrm{D}$ visualization technology to manage safety throughout the metro's construction.

All of the aforementioned research has focused on simulating the 4D approach (3D digital model + time). However, the idea of a 4D approach is hardly new. The 4D simulation approach is different from the BIM-based as-built schedule updating system, for which there have only been a few studies. In Taiwan, there have been many problems encountered with this system of scheduling during the construction phase (Lin 2009). One such problem is that it is difficult to clearly explain a project without a visual representation while the schedule is being processed. In recent studies, there have been attempts to update 4D CAD models with various technologies, such as Radio Frequency Identification (RFID) (Azimi et al. 2011; Lu et al. 2011), Ultra Wide Band (UWB) (Shahi et al. 2013), 3D laser scanning (El-Omari, Moselhi 2008, 2009; Bosche et al. 2006, 2008; Tang et al. 2010; Turkan et al. 2012; Kim et al. 2013b; Xiong et al. 2013), and digital image processing (Kim et al. 2013a). These approaches still have a multitude of limitations, such as a high cost, that need to be addressed before the methods can be put into practice. Therefore, in this work it was a challenge to provide for the general contractor and onsite engineers a platform with which they could track and manage the BIM-assisted as-built schedule.

\section{Research method}

Visual representations aid communication amongst project staff and facilitate decision making, and, when implemented well, they can provide the project team with clear and fast feedback. Currently, there is much commercial BIM software to provide the $4 \mathrm{D}$ simulation for construction management. Tekla, for example, provides BIM value beyond design to virtual construction and project time simulation. Autodesk Navisworks functions to simulate construction schedules and logistics in $4 \mathrm{D}$ to visually communicate and analyze project activities. Vico software provides $3 \mathrm{D}$ model elements connected to tasks for 4D simulation. However, this software mainly provides users with the $4 \mathrm{D}$ simulation functionality. If the general contractor wants to utilize the commerce BIM software for the application of as-built schedule management, most 4D simulation functionality is incapable of meeting the requirement of updating the as-built schedule management in practice.

To remedy the problems in the visual updating of the as-built schedule, this study presents the novel ConBIM-SM system to visually update the as-built schedule information for construction project participants. The proposed ConBIM-SM system improves project control efficiency and cost-effectiveness, enhances construction updating of as-built schedule information among project participants, and increases flexibility in updating the as-built project schedule and response time. The main objectives of this study are as follows: (1) develop a web-based BIM-assisted as-built schedule management system; (2) apply the proposed system for onsite asbuilt schedule updating and explore its limitations and problems based on a real case study; and (3) improve project BIM-assisted as-built schedule control and management efficiency for general contractors. The system will enhance dynamic project tracking and management; therefore enabling project participants to access the most up-to-date as-built schedule.

Updating the as-built schedule during the construction phase is generally recognized as the most critical strategy for successful schedule management. This study focuses on the practical implementation of the as-built schedule for the general contractor at a jobsite. In this study, the proposed ConBIM-SM system facilitates different statuses of as-built schedule process during the construction phase. In order for the project manager and project engineers to track the visual BIM-assisted as-built schedule, the study proposes five types of process statuses for updating the as-built schedule in the ConBIMSM system. The five process statuses include: (1) ahead 
of schedule with under construction status; (2) ahead of schedule with completion status; (3) behind schedule with pre-construction status; (4) behind schedule with under construction status; and (5) behind schedule with completion status. Various statuses have been developed for different purposes in order to meet distinct requirements for the as-built schedule.

The proposed ConBIM-SM system with BIM-assisted visualization allows all project engineers to access the most recent visual as-built schedule using the BIM model. Furthermore, the updated as-built schedule can also be shared with marked information related to changes (Fig. 1). The primary advantages of the BIMassisted as-built schedule are as follows: (1) it provides a BIM-assisted illustration for sharing the updated asbuilt schedule in the web environment; (2) it provides project managers and engineers with the ability to track color-assisted statuses of all virtual as-built schedule processes during the construction phase of a project; and (3) it gives project engineers the ability to respond to the updated or feedback content using the BIM approach in practice.

The study utilizes the BIM approach to apply asbuilt BIM models in the updating of the as-built schedule. In the study, Design Web Format (DWF) is the selected format of the BIM file for markup as-built schedule use. Onsite engineers may update the status and corresponding color of the progress using as-built BIM models (BIM DWF file), and upload it to the system for updated as-built schedule sharing. Finally, the system will convert as-built updated component units of BIM models under the BIM DWF file by API programming and upload them to the ConBIM-SM system.

The study proposes a new innovative multi-field updated approach to the as-built schedule to enhance its management, which in turn allows engineers to update multiple as-built records of each activity or task in the field at various times. The main purpose is for engineers to build upon the previous updated content for each ac-

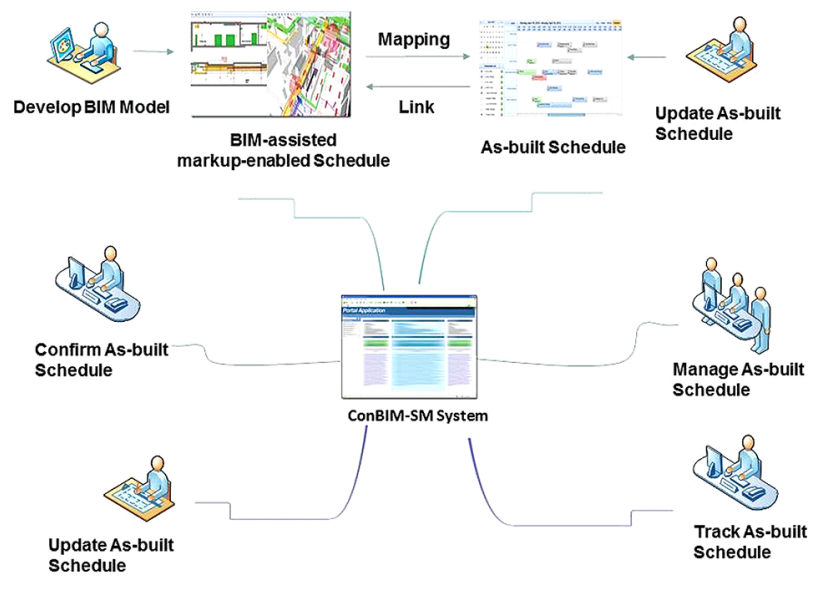

Fig. 1. The concept and framework of the ConBIM-SM system tivity or task. This multi-field updated as-built schedule approach allows engineers to track past and present progress of the as-built schedule content. When onsite engineers also select a traditional single field for as-built updates, they need not use a multi-field progress update system.

The 3D markup-enabled schedule models can be defined as a 3D CAD graphic representation of as-built schedule activities linking relationships between CAD objects and attributes of schedule models. The BIM approach retains as-built schedule information in a digital format, facilitating easy updating and transfer of activities in the 3D CAD environment. The as-built schedule information with 3D BIM approach can be identified, tracked, and managed virtually during construction projects. The most recent as-built schedule status and comments can be acquired from onsite engineers and then shared and illustrated by way of the 3D BIM model for better understanding and communication.

The 3D markup-enabled schedule models, which are defined in multiple objects, are constructed from variables that can be decomposed into CAD component units and cam store the status of the as-built activity schedule. The 3D markup-enabled schedule models allow users to access information from the as-built schedule stored in layers based on the attributes and type of the as-built schedule. As-built schedule information stored in components of the 3D markup-enabled schedule model includes both the status of the as-built schedule and comments (Fig. 2). As-built activity schedule status includes the as-built schedule, comments of the as-built schedule, descriptions of problems regarding the as-built schedule, or related attachments (e.g. documents, reports, drawings, and photos). Additionally, the 3D markup-enabled schedule models allow users to review the as-built schedule with the BIM model to enhance effectiveness of visual communication. The 3D markup-enabled schedule model is associated with the as-built schedule, locations, and comments on activities.

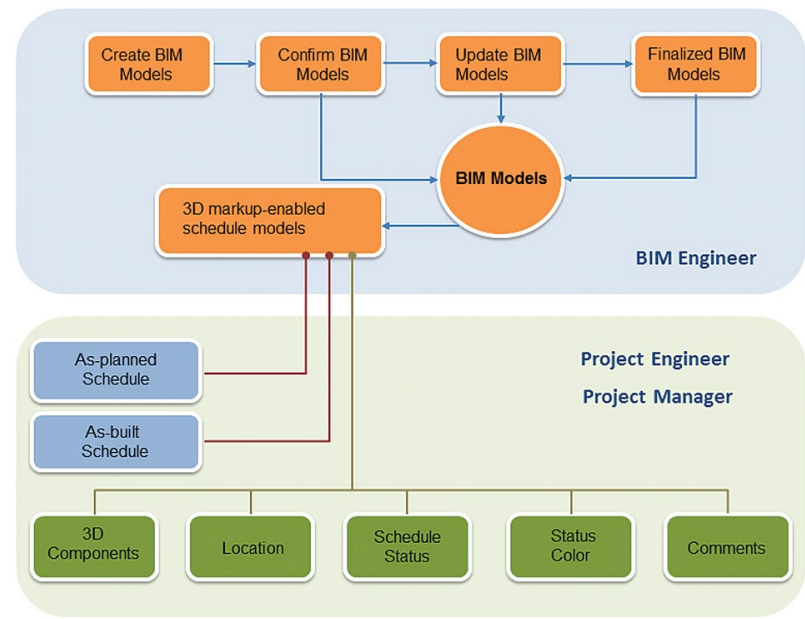

Fig. 2. Concept of BIM-assisted visualization integrated with the as-built schedule in the ConBIM-SM system 


\section{System development}

\subsection{System overview}

The following section describes the development of the proposed ConBIM-SM system. The developed ConBIMSM system runs on Microsoft Windows 2008 software with an Internet Information Server (IIS) as the web server. The ConBIM-SM system is developed using ASP.NET, which are easily incorporated with HTML and JavaScript technologies. The ConBIM-SM system server supports four distinct layers: interface, access, application, and database (Fig. 3). Each layer has its own responsibilities. The interface layer defines administrative and end-user interfaces. Users can access information via web browsers such as Microsoft Internet Explorer or Google Chrome. Administrators control and manage information via the web browser or using a separate server interface. The access layer provides system security and restricted access, firewall services, and system administration functions. The application layer defines various applications for analyzing and managing information. The database layer consists of a primary Microsoft SQL Server 2003 database. A firewall and virus scanning capability are used to protect the system database against intrusion.

The ConBIM-SM system is designed for all BIMrelated project participants via a user-friendly portal, which serves as a real-time, updated as-built schedule channel for project engineers. All data are stored and classified using the visual schedule management dashboard in the ConBIM-SM system. Furthermore, the ConBIM-SM system is a solution that uses a single, unified database linked to the as-built models' files (DWF files) with different levels of access determined by user roles. Participants can access the BIM model SM information entry and updates, based on their responsibilities in the ConBIM-SM system. When information is updated in the ConBIM-SM system, the server automatically sends emails to the project manager, and the project engineers associated with the issue. One purpose in this study is to extend BIM to the construction phase and provide asbuilt schedule updating service for general contractor.
The as-built model is applied in the ConBIM-SM system to capture and store as-built model information. Autodesk Revit Architecture and Revit MEP were used to model the BIM management dashboard and create BIM files. Autodesk Design Review was used to read as-built model files from the BIM management dashboard. Information integration with the BIM management dashboard was achieved using the Autodesk Revit application programming interface (API) and Microsoft Visual Basic. Net (VB.NET) programming language. The ConBIMSM system was developed by integrating the BIM SMrelated information using Autodesk Revit Architecture and Revit MEP software. All APIs in the ConBIM-SM system were programmed in VB.NET using Revit API. A program in $\mathrm{C}++$ was written to integrate acquired data from different software programs and all interface information, such that as-built model files could be exported to an ODBC database for connection with the ConBIM-SM system. If all as-built schedule information is recorded in the BIM model, the load of the BIM model is too large for the system. BIM models cover a wealth of building information; stored information should be for crucial information, such as schedule component ID, names of the schedule components, and other critical information. In order to maintain the system's level of performance, the derived as-built schedule information should be stored in another location. Therefore, there are two databases designed in the ConBIM-SM system. They are the BIM elements database and the ConBIM-SM database. The BIM elements database only store basic information (such as components of BIM position, ID and names of schedule components, and key parameter information of the components). Furthermore, the as-built schedule information of ConBIM-SM is stored in the ConBIM-SM database.

\subsection{System modules}

This section demonstrates the implementation of the ConBIM-SM system modules.

\section{Authority management module}

The authority management module is an access control mechanism preventing unauthorized users from

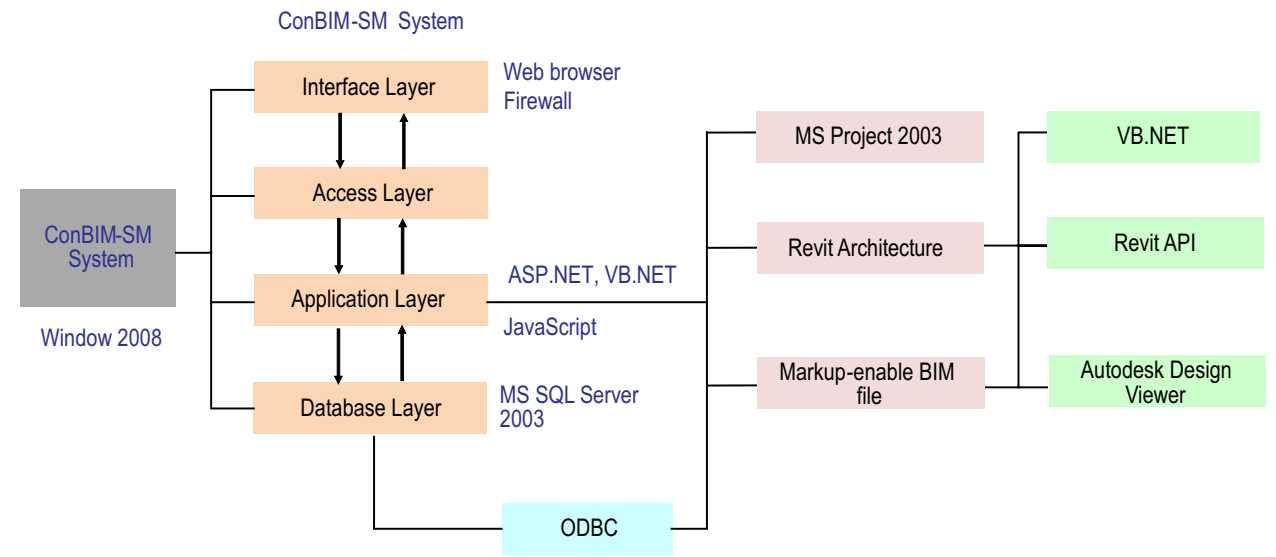

Fig. 3. ConBIM-SM system architecture 
entering the system or retrieving sensitive as-built schedule information. The ConBIM-SM system requires all project engineers, project managers, BIM engineers, and system administration to register. To register, users provide a unique User ID and password for authentication. As ConBIM-SM information and reports required by different project engineers and different BIM models vary, the authority and access rights of project managers and BIM engineers vary from those of others.

\section{BIM process monitoring module}

The BIM process monitoring module tracks provide the visual BIM-assisted updating schedule management dashboard environment. Additionally, project engineers and managers can access visual schedule management dashboard regarding the current process or status of the as-built schedule information. The process monitoring module has an easy access option that allows participants to track as-built schedule information with different status color of BIM models illustration. Furthermore, project engineers and project managers can share the most recent updated as-built schedule with related BIM models and access all current responses about schedule problems with an as-built model from onsite project engineers.

\section{Alert management module}

The alert management module helps the project engineers, who set up an alert service to monitor and manage the updating of as-built schedule via e-mail and RSS feed. Dates related to the notification about updates in BIM-assisted schedule information are recorded systematically. Furthermore, this module provides convenient access and a push-based function to help the project manager and project engineers respond to decisions in advance, before an update in the schedule is tracked and others respond.

\section{BIM models update management module}

The BIM models update management module lets users update the as-built schedule information regarding selection of BIM model components, which are stored with the corresponding as-built models in DWF files. Authorized records for updating as-built schedule information can be extracted and summarized for the BIMassisted updating schedule summary. Furthermore, the entire BIM-assisted updating schedule summary can be presented on the web or extracted using commercially available software such as Adobe Acrobat.

\section{BIM models problem response module}

The module centralizes storage of all problems of the corresponding components of the as-built schedule in the 3D BIM model in a visual environment. This allows onsite engineers to respond effectively from a central location to problems in the as-built schedule and provide a revised description of corresponding modified as-built models (DWF files). Usually, the onsite engineer can submit the problem in the as-built schedule information about corresponding components in the 3D BIM model through the module. Furthermore, project participants can communicate problems with the BIM-assisted asbuilt schedule through the module.

\section{BIM SM report module}

The module allows users to easily access the brief updates in information about BIM schedule regarding the corresponding components in the 3D BIM model. Authorized records for updating the as-built schedule can be extracted and summarized with the visual BIM model reports. Furthermore, all BIM SM reports can be presented on the web or extracted using commercially available software such as Microsoft Word and Acrobat PDF.

\section{Case study}

\subsection{Case description}

The case study was a 4-months construction project. The case study involves a general contractor with 25 years of experience in constructing office buildings in Taiwan. The construction phase of this office-building project also involves three subcontractors and five suppliers. The general contractor wanted to take full advantage of using the visual approach to enhance onsite construction management (aspects of which include schedule management, visual discussion, and so on). In the general contractor's previous experience, there have been serious problems with onsite as-built schedule updating and tracking. One such problem has been obtaining an accurate position and location from the text-based illustrations of a traditional schedule. Therefore, the general contractor had assigned project engineers, project managers, and BIM engineers to utilize the ConBIM-SM system to solve the problems related to the onsite as-built schedule during the construction phase. The ConBIM-SM system was used in the office-building project to demonstrate its efficacy and that of the visual BIM-assisted updating and management of the as-built schedule.

A major aim of selecting this project was to emphasize the general contractor's use of BIM tools to manage construction as-built schedule during the construction phase. All BIM models were created and developed by the general contractor. The main benefits of using BIM in construction for general contractor included less rework, better cost estimation, and improved productivity. Therefore, the general contractor decided to reuse these BIM models to enhance the application of visual BIM as-built schedule management. In other words, the BIM models were reused and applied to as-built schedule management. There were two full-time engineers with three years of BIM experience to perform the BIM asbuilt schedule management in the project. The ConBIMSM system was installed on the general contractor's main server during the test. A user guide was provided, and three ConBIM-SM system workshops were held to demonstrate the use of the ConBIM-SM system. All invited engineers originally used the Microsoft Project software 
to control the project schedule. During the test period, they used the ConBIM-SM system only for the test project and used Microsoft Project to control the schedule and management of the company simultaneously. During the case study, responsible onsite engineers updated their as-built schedule, and updated the status and content of the BIM model in the ConBIM-SM system. The BIM engineers needed to prepare and convert all BIM models into DWF files in the initial phase. After the BIM models were converted, the onsite engineers linked the as-built activity with the read-only BIM model (DWF files) and uploaded the submission via the ConBIM-SM system. The attached files with selected components of the BIM model included digital documents and photos. The BIM engineers assisted the onsite engineer in the creation and conversion of the BIM models for use in future as-built scheduling. Furthermore, BIM engineers will revise the BIM models based on the as-built situation, if necessary. All onsite engineers were required to update the as-built schedule using the ConBIM-SM system. Onsite engineers updated the status color of the current schedule's components that corresponded with the BIM models (DWF file), and updated their discussions and comments via the ConBIM-SM system. Finally, all BIM-assisted schedule information was centralized and stored in the central database to prevent the collection of redundant data. The ConBIM-SM system automatically sent a message concerning any updated information to the onsite engineers and project manager after saving the new content.

In the case study, the decoration engineers attempted to utilize the BIM approach for illustrating the as-built updated schedule regarding the installation of windows and doors. The decoration engineers and BIM engineers utilized the as-built BIM models and linked the BIM models to the activity in the ConBIM-SM system. After the as-built BIM models were revised and linked with related activities, the decoration engineers were invited to update their as-built schedules with the BIM approach. All decoration engineers were required to update their own as-built schedules regarding the activities for which they were responsible. The as-built schedule information with the corresponding components of the BIM models included the as-planned schedule, as-built schedule, descriptions and comments, and as-built photos (when they were necessary). When the submitted as-built schedule document set was approved by the project manager, the system illustrated the process automatically. In other words, users could find and read the related as-built schedule directly simply by clicking on activities and referring to the corresponding components of the BIM models. Finally, all submitted as-built schedules whose components corresponded with the BIM models had to have their performance quality approved before the final as-built schedule could be published. All of the validation needed to be executed by the project manager.

The decoration engineer identified and updated the as-built schedule records of selected decorations (such

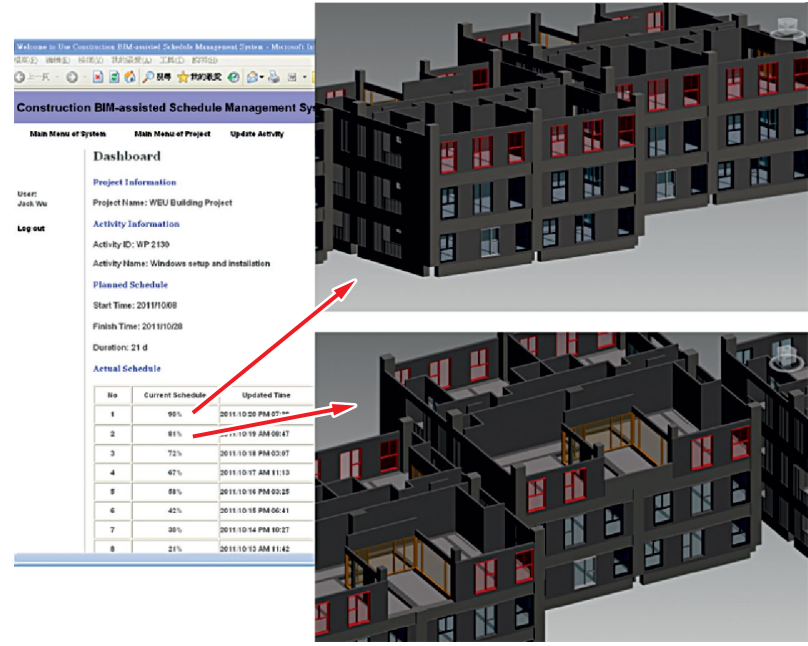

Fig. 4. As-built schedule update information with BIM-assisted visualization in the case study

as descriptions, as-built photos, and documentation) provided by the responsible engineers (Fig. 4). The decoration engineer continued to update and provide comments on the as-built schedule in the portion of the project assigned to the installation of windows and doors using the multi-field as-built schedule records. Additionally, the decoration engineer provided additional suggestions and feedback pertaining to any delay problems after the work was completed. Subsequently, another decoration engineer updated the new as-built schedule and selected the status of the as-built schedule in the ConBIM-SM system after completing the installation of the windows and doors. Furthermore, the engineer uploaded the as-built photos and descriptions of the components corresponding to the BIM models in the ConBIM-SM system. Moreover, the decoration engineer republished the updated asbuilt schedule from the approval section to the published section of the ConBIM-SM system after the approval process was completed, and a notification was sent to authorized members. Figure 5 illustrates the flowchart of the process used in the ConBIM-SM system in this case.

\subsection{Field tests and results}

During the field test, the three BIM engineers handled all the BIM-related work. The BIM works included the as-built schedule integrated with BIM models creation, modification, and revision. The twelve onsite project engineers and the general contractor handled the entire construction project up to its completion using the as-built schedule. The ConBIM-SM system was installed on the general contractor's main server during the test. A user guide was given and two ConBIM-SM system workshops were held to show how the ConBIM-SM system could be integrated with the BIM approach. Furthermore, BIM-related software (Autodesk Revit Architecture and Autodesk Revit MEP) was selected to create and revise the as-built models. All BIM files were converted into DWF files for review and markup in the ConBIM-SM system. 


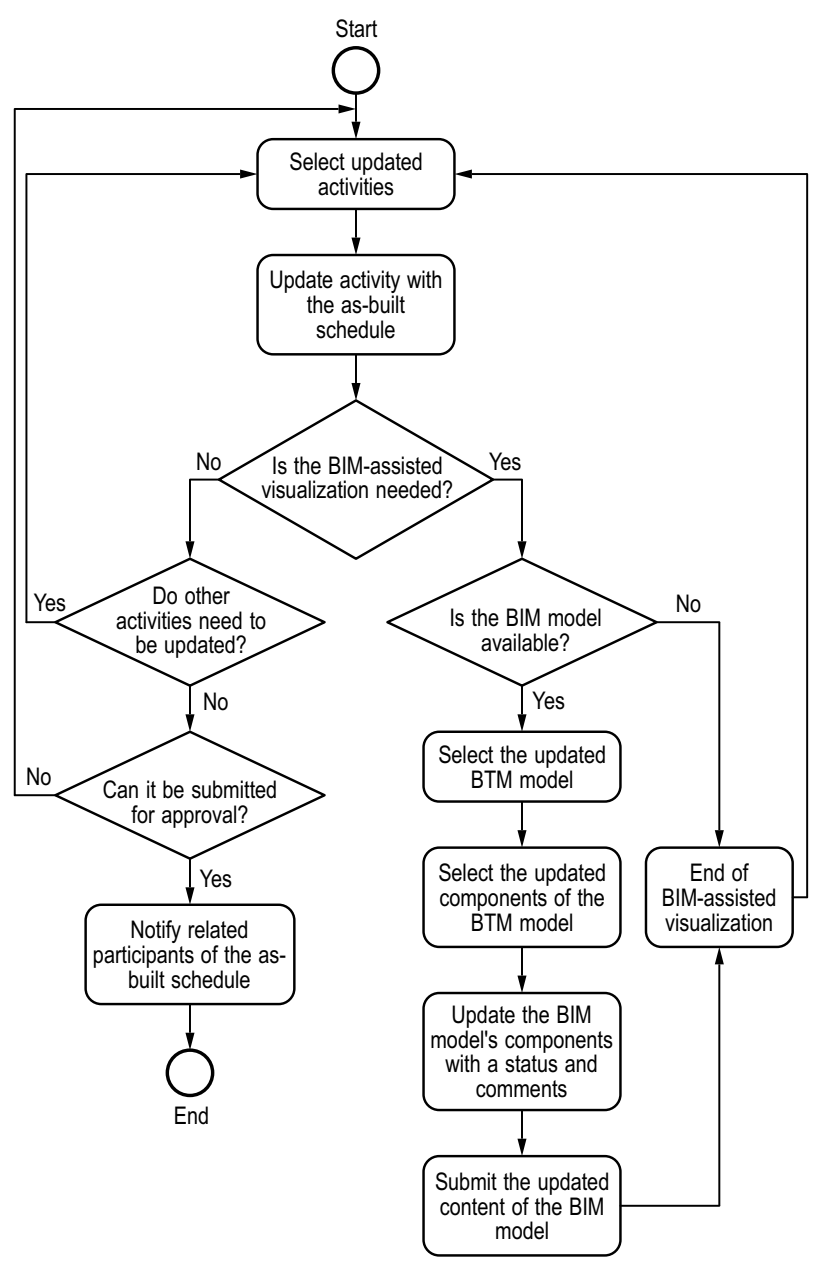

Fig. 5. The flowchart of the process used in the ConBIM-SM system

In this case study, the BIM engineer handled and assisted the production and revision of BIM models for BIM-assisted as-built scheduling. The onsite engineers developed and updated the BIM-assisted as-built schedule. Finally, the project managers and onsite engineers accessed and tracked the updated as-built schedule with the BIM approach in the ConBIM-SM system.

During the field test, the verification test was carried out through the assessment of whether the ConBIM-SM system performed tasks as specified in its design. During the validation test, selected case participants were asked to use the system; case participants then provided feedback via a questionnaire. The case participants consisted of three BIM engineers of general contractor with three years' experience, six onsite engineers with five years' experience, two senior subcontractor engineers with ten years' experience, and two general contractor project engineers with ten years' experience. Questionnaires were distributed to evaluate system function and user satisfaction with system capabilities. System users were asked to grade the system's usage, functionality, and capability separately, based on a comparison with the previous meeting approach on a five-point Likert scale, ranging from 1 for "not useful" to 5 for "very useful". Questionnaire results indicated that enhancing the management of the visual as-built updated schedule with graph visualization using the BIM approach was significantly improved through the use of the proposed system. Comments regarding possible improvements to the ConBIM-SM system were also obtained from project participants. The ConBIM-SM system was demonstrated to the respondents, who were asked to express their opinions towards the system by completing the questionnaire. Table 1 shows the results of the testing of the system.

Table 1. System evaluation result

\begin{tabular}{ll}
\hline \multicolumn{1}{c}{ System Evaluation Item } & Mean Score \\
\hline Enhance visual as-built schedule illustration & 4.5 \\
\hline Applicability to construction industry & 4.8 \\
\hline Reduces mistakes in as-built schedule & 4.2 \\
\hline Enhances virtual as-built schedule sharing & 4.3 \\
\hline $\begin{array}{l}\text { Enhances tracking as-built schedule status } \\
\text { virtually }\end{array}$ & 4.2 \\
\hline $\begin{array}{l}\text { Improves updating as-built schedule } \\
\text { sharing }\end{array}$ & 4.5 \\
\hline $\begin{array}{l}\text { Enhances BIM-assisted schedule } \\
\text { communication }\end{array}$ & 4.4 \\
\hline $\begin{array}{l}\text { Enhances updated parts of as-built } \\
\text { schedule }\end{array}$ & 4.1 \\
\hline $\begin{array}{l}\text { Enhances managing as-built schedule } \\
\text { virtually }\end{array}$ & 4.3 \\
\hline Note: the mean score is calculated from respondent feedback
\end{tabular}

Note: the mean score is calculated from respondents' feedback on a five-scale questionnaire: 1(Strongly Disagree), 2, 3, 4 and 5 (Strongly Agree).

The principal advantages of the ConBIM-SM system, based on questionnaire results, are as follows: (1) The ConBIM-SM system allowed project engineers and managers to track and manage the visual BIM-assistant as-built schedule information during construction (92\% agreed); (2) The ConBIM-SM system allowed onsite engineers to provide as-built schedule feedback with color-coded statuses through the ConBIM-SM system (89\% agreed); (3) The ConBIM-SM system enabled the project engineers to track and view the updated contents of the as-built schedule when using it with the BIM approach (88\% agreed); (4) The ConBIM-SM system enhanced visual management of the as-built schedule effectively in the visual environment ( $92 \%$ agreed).

The following recommendations are based on user feedback: (1) Successful ConBIM-SM adoption should be supported by the individuals of highest authority in a firm and on a jobsite; (2) Policy and strategy must be considered to encourage use of the ConBIM-SM system at the jobsite during the construction phase; (3) Further efforts and additional approaches are required to overcome unwillingness to adopt BIM software (such as Autodesk Design Review) at a construction jobsite; (4) Initial case study results should be used to educate users about adoption of BIM software, and additional staff training is needed; (5) Further training and workshops on the ConBIM-SM system and BIM software are necessary for all users. 


\subsection{Barriers and limitations}

User feedback indicated that the primary barriers to using the ConBIM-SM system were as follows: (1) Most onsite engineers were unsatisfied with the slow Internet speed at the jobsite; (2) Substantial amounts of time and assistance were needed for engineers and managers to update the as-built schedule with the BIM approach; (3) A few project engineers were difficult to update as-built schedule and feedback results because of insufficient time; (4) Two senior project engineers had difficulty becoming familiar with utilizing 3D BIM models; and (5) The size of the DWF files directly affected the ConBIM-SM system's operation performance.

The findings of this case study revealed several limitations of the ConBIM-SM system. The following are inherent problems recognized during the case study:

- An initial plan or discussion to integrate the BIM models in BIM-assisted schedule management is necessary at the project's onset to avoid ensuing problems with the as-built schedule updated with the BIM approach.

- Generally, BIM at different levels of detail (LOD) will affect the results of the visual updates to the as-built schedule. For example, a BIM model with LOD400 makes it easier to update the as-built schedule than one with LOD100. The corresponding components of a BIM model with LOD100 will require more detail for schedule updating than a BIM model with LOD400.

- In the case study, project engineers who were unfamiliar with the use of 3D BIM models initially required additional time to apply the corresponding BIM-assisted as-built schedule in the ConBIM-SM system. Therefore, more time was used with this system than the current approach. After the users became more skilled and familiar with the 3D BIM models, the amount of time necessary for the current approach was almost identical to the time necessary for the proposed system in utilizing 3D BIM models.

- Onsite project engineers who experienced a pressing work schedule often lacked sufficient time and assistance to update the as-built schedule. Additionally, the attitudes of the project engineers involved in the use of the ConBIM-SM system to update the as-built schedule were found to vary greatly. The development of systems that satisfies all the needs of the various project engineers depends on their contrasting viewpoints and attitudes.

- Support of the upper management helps to assure the implementation of the updated as-built schedule, especially at the jobsite. In the case study, overcoming resistance to using the 3D BIM models and ConBIM-SM system by onsite engineers during their work was an important factor, as well as one of the major prerequisites for the successful implementation of the ConBIM-SM system. Upper management, therefore, gave project participants an incentive/bonus reward for using the ConBIMSM system more consistently during the case study. Future research must address how an updated BIM model can be implemented onsite effectively and directly (including BIM model creation, modification, updating) in practice.

- Given the limited storage capacity of any PC and notebook, it is suggested that the BIM engineer create in advance the DWF files in the database for referring to BIM models and helping the asbuilt schedule to support advanced BIM-assisted schedule management systems to be used in construction management. However, the size of a DWF file will directly and obviously affect the operation performance of the ConBIM-SM system. The size will affect the time used to read the DWF files and search for facilities, as well as the system's operation efficiency. Therefore, the original BIM model (a DWF file) will need to be converted into many smaller BIM models (DWF files).

- The ConBIM-SM system can only be used at the jobsite directly. The findings of the case study indicate that most onsite engineers updated their as-built schedule when they were at the jobsite. The case study revealed that most onsite engineers considered updating their as-built schedule at the jobsite using a smart phone or notebook in a Wi-Fi or $3 \mathrm{G}$ environments to be inconvenient. Therefore, onsite engineers began using tablet computers (such as iPads) which, according to case observations, improved their willingness to apply the ConBIM-SM system and update their as-built schedule directly at the jobsite.

- In this case study, many onsite engineers chose to use the proposed multi-field as-built schedule's progress records to facilitate tracking the updated as-built schedule with the BIM approach in the ConBIMSM system. According to the questionnaire's results, most of the engineers thought the use of multifield as-built schedule records was very helpful for updating progress and tracking management, although the BIM-assisted as-built schedule could be very time-consuming.

- Regarding the use of various colors in the BIM model for updating and tracking purposes, it is recommended to limit the amount of different colors used, so as to reduce confusion for the user. Additionally, the next steps in the system's development are providing users with the $2 \mathrm{D}$ illustration map for updating the condition of the schedule, identifying the 2D location, and reviewing the $3 \mathrm{D}$ visual BIM model in the future. 


\section{Conclusions}

Various visual representations of a project's schedule and associated information combined with visual representations of the project in progress, i.e. BIM, can assist with these tasks of identifying effective construction strategies for managing a project's duration. The application of BIM integrated with an as-built updated schedule for building projects during the construction phase is discussed in this work. To assist the general contractor in effectively and efficiently managing updates to the asbuilt schedule, this study develops the ConBIM-SM system for managers and engineers. This system utilizes visual BIM-assisted illustration. Through a BIM-assisted web environment, the ConBIM-SM system can give project engineers the updated content of the as-built schedule through the markup-enabled BIM models.

There is a great deal of research focusing on the simulation of the 4D approach (3D and time simulations), although the idea of the 4D approach is not new. There are few studies on updating an as-built schedule using the BIM approach. Notably, the proposed approach retains information about changes and conditions to the as-built schedule in a digital format and facilitates easy and effective visual updating of as-built schedule information in the web environment. Furthermore, project participants can access and utilize the most recently updated as-built schedule integrated with the BIM application in practice during the construction phase. All as-built schedules can be updated, and changes and problems are made known to each project engineer via the markup-enabled BIM models. Finally, the proposed ConBIM-SM system is applied to a case study of a building project in Taiwan to verify its efficacy and demonstrate its ConBIM-SM system's effectiveness. The case study results show that the ConBIM-SM system provides users with centralized storage of all updates to the contents and status of the asbuilt schedule during the construction phase of a project, such that the project managers and project engineers can track and manage the visual status effectively. The case study also highlights the need to improve onsite BIM SM work during the construction phase. Integration of webbased technologies and the BIM approach is promising for the alleviation of problems in updating an as-built schedule during the construction phase. Overall, field test results indicate that the proposed ConBIM-SM system is an effective and user-friendly platform for the general contractor to handle construction work using an as-built schedule integrated with the application of BIM.

This study presented the ConBIM-SM system to construction project participants so that they could update and share any information about their as-built schedule in an enhanced visual way. The proposed system effectively improves the efficiency and effectiveness of creating a visual of the updated as-built schedule, thus enabling the general contractor to control and manage progress at the jobsite. The ConBIM-SM system improves efficiency in tracking the as-built schedule information collected visually from onsite engineers, and provides monitoring services for project participants. This study shows that the ConBIM-SM system significantly enhances control of the visual aspect of a construction project's as-built schedule. The system also enhances construction management when it is integrated with the application of BIM. Furthermore, the BIM-assisted visual illustration of real-time as-built information from all project participants helps the general contractor's manager to visually monitor and control the construction project's as-built scheduling process by using statuses of various colors. One of the main characteristics of the ConBIMSM system is that there is no requirement for updating the BIM-assisted as-built schedule to install any BIM software at jobsite. All that any individual needs to do is to install the free Autodesk Design Review software and access the ConBIM-SM system directly through Microsoft Internet Explorer or Google Chrome. Project participants and managers can access the ConBIM-SM system to track the BIM-assisted as-built schedule anytime and anywhere, based on what they are permitted to do by their authorities.

Because $\mathrm{nD}$ modeling uses the BIM approach, it is critical to examine BIM's practicality on a jobsite. In the future, $\mathrm{nD}$ modelling will be considered for practical use and research on a jobsite. Over the past few years, there has been a great deal of studies on the application of $\mathrm{nD}$ modelling. However, most of these ideas have not actually been put to use on a jobsite. Future development of and research on the ConBIM-SM system will explore the mechanisms and interfaces that will be necessary if $\mathrm{nD}$ modelling is to be used on a jobsite. These advances aim to ultimately lead to the system's more comprehensive practical use. Consequently, cost analysis will come to play a key role in the ConBIM-SM system as it is developed further.

\section{Acknowledgements}

The authors would like to express their appreciation to $\mathrm{D}-\mathrm{W}$ Construction Inc. for assistance in the system design and interviews, and to the project owner's experts and engineers for providing useful data, valuable information, and helpful comments during system design and development.

\section{References}

Arayici, Y.; Coates, P.; Koskela, L.; Kagioglou, M.; Usher, C.; O'Reilly, K. 2011. Technology adoption in the BIM implementation for lean architectural practice, Automation in Construction 20(2): 189-195.

http://dx.doi.org/10.1016/j.autcon.2010.09.016

Azhar, S. 2011. Building Information Modeling (BIM): trends, benefits, risks, and challenges for the AEC industry, Leadership and Management in Engineering 11(3): 241-252. http://dx.doi.org/10.1061/(ASCE)LM.1943-5630.0000127

Azimi, R.; Lee, S. H.; AbouRizk, S. M.; Alvanchi, A. 2011. A framework for an automated and integrated project monitoring and control system for steel fabrication projects, Automation in Construction 20(1): 88-97. http://dx.doi.org/10.1016/j.autcon.2010.07.001 
Barlish, K.; Sullivan, K. 2012. How to measure the benefits of BIM - a case study approach, Automation in Construction 24: $149-159$. http://dx.doi.org/10.1016/j.autcon.2012.02.008

Becerik-Gerber, B.; Rice, S. 2010. The perceived value of building information modeling in the US building industry, Journal of Information Technology in Construction (ITcon) 15: 185-201.

Bosche, F.; Teizer, J.; Haas, C. T.; Caldas, C. H. 2006. Integrating data from $3 \mathrm{D} \mathrm{CAD}$ and $3 \mathrm{D}$ cameras for real-time modeling, in Joint International Conference on Computing and Decision Making in Civil and Building Engineering, June, 2006, Montreal, QC, Canada. 9 p.

Bosche, F.; Haas, C. T.; Murray, P. 2008. Performance of automated project progress tracking with $3 \mathrm{D}$ data fusion, in Proc. of CSCE Annual Conference, 10-13 June, 2008, Quebec, QC, Canada. 10 p.

Chau, K.; Anson, M.; Zhang, J. 2004. Four-dimensional visualization of construction scheduling and site utilization, Journal of Construction Engineering and Management 130(4): 598-606.

http://dx.doi.org/10.1061/(ASCE)0733-9364(2004)130:4(598)

Chavada, R.; Dawood, N.; Kassem, M. 2012. Construction workspace management: the development and application of a novel $\mathrm{nD}$ planning approach and tool, Journal of Information Technology in Construction (ITcon) 17: 213-236.

Davidson, I.; Skibniewski, M. 1995. Simulation of automated data collection in buildings, Journal of Computing in Civil Engineering 9(1): 9-20. http://dx.doi.org/10.1061/(ASCE)0887-3801(1995)9:1(9)

Davies, R.; Harty, C. 2013. Implementing 'Site BIM': a case study of ICT innovation on a large hospital project, Automation in Construction 30: 15-24. http://dx.doi.org/10.1016/j.autcon.2012.11.024

Eastman, C.; Teicholz, P.; Sacks, R.; Liston, K. 2011. BIM handbook: a guide to building information modeling for owners, managers, designers, engineers and contractors. $2^{\text {nd }}$ ed. New Jersey: John Wiley and Sons, Inc. 504 p.

Elbeltagi, E.; Dawood, M. 2011. Integrated visualized time control system for repetitive construction projects, Automation in Construction 20(7): 940-953. http://dx.doi.org/10.1016/j.autcon.2011.03.012

El-Omari, S.; Moselhi, O. 2008. Integrating 3D laser scanning and photogrammetry for progress measurement of construction work, Automation in Construction 18(1): 1-9. http://dx.doi.org/10.1016/j.autcon.2008.05.006

El-Omari, S.; Moselhi, O. 2009. Data acquisition from construction sites for tracking purposes, Engineering, Construction and Architectural Management 16(5): 490-503. http://dx.doi.org/10.1108/09699980910988384

$\mathrm{Gu}, \mathrm{N}$.; London, K. 2010. Understanding and facilitating BIM adoption in the AEC industry, Automation in Construction 19(8): 988-999.

http://dx.doi.org/10.1016/j.autcon.2010.09.002

Hardin, B. 2009. BIM and construction management: proven tools, methods, and workflows. New Jersey: John Wiley and Sons, Inc. 364 p.

Hartmann, T.; Meerveld, H. V.; Vossebeld, N.; Adriaanse, A. 2012. Aligning building information model tools and construction management methods, Automation in Construction 22: 605-613. http://dx.doi.org/10.1016/j.autcon.2011.12.011

Heesom, D.; Mahdjoubi, L. 2004. Trends of 4D CAD applications for construction planning, Construction Management and Economics 22(2): 171-182. http://dx.doi.org/10.1080/0144619042000201376

Hegazy, T.; Abdel-Monem, M. 2012. Email-based system for documenting construction as-built details, Automation in
Construction 24: 130-137.

http://dx.doi.org/10.1016/j.autcon.2012.02.014

Hu, Z.; Zhang, J. 2011. BIM- and 4D-based integrated solution of analysis and management for conflicts and structural safety problems during construction: 2 . Development and site trials, Automation in Construction 20(2): 167-180. http://dx.doi.org/10.1016/j.autcon.2010.09.014

Irizarry, J.; Karan, E. P.; Jalaei, F. 2013. Integrating BIM and GIS to improve the visual monitoring of construction supply chain management, Automation in Construction 31: 241-254. http://dx.doi.org/10.1016/j.autcon.2012.12.005

Jung, Y.; Joo, M. 2011. Building information modelling (BIM) framework for practical implementation, Automation in Construction 20(2): 126-133.

http://dx.doi.org/10.1016/j.autcon.2010.09.010

Kim, C.; Kim, H.; Park, T.; Kim, M. 2011. Applicability of 4D $\mathrm{CAD}$ in civil engineering construction: case study of a cable-stayed bridge project, Journal of Computing in Civil Engineering 25(1): 98-107.

http://dx.doi.org/10.1061/(ASCE)CP.1943-5487.0000074

Kim, C.; Kim, B.; Kim, H. 2013a. 4D CAD model updating using image processing-based construction progress monitoring, Automation in Construction 35: 44-52. http://dx.doi.org/10.1016/j.autcon.2013.03.005

Kim, C.; Son, H.; Kim, C. 2013b. Automated construction progress measurement using a 4D building information model and 3D data, Automation in Construction 31: 75-82. http://dx.doi.org/10.1016/j.autcon.2012.11.041

Li, H.; Chan, K. Y.; Skitmore, M. 2012. The use of virtual prototyping to rehearse the sequence of construction work involving mobile cranes, Construction Innovation: Information, Process, Management 12(4): 429-446.

Lin, Y. C. 2009. Interface problems and methods for general contractor in Taiwan construction projects, in Proc. of 2009 PM Conference, 2009, Taiwan, 192-197.

Liston, K. M.; Fischer, M.; Kunz, J. 1998. 4D annotator: a visual decision support tool for construction planners, computing in civil engineering, in Proc. of the International Computing Congress, 18-21 October, 1998, Boston, USA, 330-341.

Lu, W.; Huang, G. Q.; Li, H. 2011. Scenarios for applying RFID technology in construction project management, Automation in Construction 20(2): 136-143. http://dx.doi.org/10.1016/j.autcon.2010.09.007

Manning, R.; Messner, J. 2008. Case studies in BIM implementation for programming of healthcare facilities, Journal of Information Technology in Construction (ITcon) 13: 446-457.

Martins, J. P.; Monteiro, A. 2013. LicA: a BIM based automated code-checking application for water distribution systems, Automation in Construction 29: 12-23. http://dx.doi.org/10.1016/j.autcon.2012.08.008

Matta, C.; Kam, C. 2010. The GSA'sBIM pilot program, presentation by GSA PBS Office of the Chief Architect [online], [cited 21 March 2010]. Available from Internet: http:// bim.arch.gatech.edu/data/reference/gsaBIM.pdf 20058.

Navon, R. 2007. Research in automated measurement of project performance indicators, Automation in Construction 16(2): 176-188. http://dx.doi.org/10.1016/j.autcon.2006.03.003

Park, C. S.; Lee, D. Y.; Kwon, O. S.; Wang, X. 2013. A framework for proactive construction defect management using BIM, augmented reality and ontology-based data collection template, Automation in Construction 33: 61-71. http://dx.doi.org/10.1016/j.autcon.2012.09.010

Porwal, A.; Hewage, K. N. 2013. Building Information Modeling (BIM) partnering framework for public construction projects, Automation in Construction 31: 204-214. http://dx.doi.org/10.1016/j.autcon.2012.12.004 
Redmond, A.; Hore, A.; Alshawi, M.; West, R. 2012. Exploring how information exchanges can be enhanced through Cloud BIM, Automation in Construction 24: 175-183. http://dx.doi.org/10.1016/j.autcon.2012.02.003

Ren, Y.; Skibniewski, M. J.; Jiang, S. 2012. Building information modeling integrated with electronic commerce material procurement and supplier performance management system, Journal of Civil Engineering and Management 18(5): 642-654. http://dx.doi.org/10.3846/13923730.2012.719835

Russell, A.; Staub-French, S.; Tran, N.; Wong, W. 2009. Visualizing high-rise building construction strategies using linear scheduling and 4D CAD, Automation in Construction 18(2): 219-236. http://dx.doi.org/10.1016/j.autcon.2008.08.001

Shahi, A.; West, J. S.; Haas, C. T. 2013. Onsite 3D marking for construction activity tracking, Automation in Construction 30: 136-143. http://dx.doi.org/10.1016/j.autcon.2012.11.027

Shen, Z.; Issa, R. 2010. Quantitative evaluation of the BIM assisted construction detailed cost estimates, Journal of Information Technology in Construction (ITcon) 15: 234257.

Tang, P.; Huber, D.; Akinci, B.; Lipman, R.; Lytle, A. 2010. Automatic reconstruction of as-built building information models from laser-scanned point clouds: a review of related techniques, Automation in Construction 19(7): 829-843. http://dx.doi.org/10.1016/j.autcon.2010.06.007

Taylor, J. E.; Bernstein, P. G. 2009. Paradigm trajectories of building information modeling practice in project networks, Journal of Management in Engineering 25(2): 69-76.

http://dx.doi.org/10.1061/(ASCE)0742-597X(2009)25:2(69)

Trupp, T.; Soibelman, L.; Hashash, T. M. A.; Liu, L. Y. 2004. Novel technologies for construction field data collection, in Proc. of the 10th International Conference on Computing in Civil and Building Engineering (ICCCBE), 2004, Weimar, Germany. 9 p.

Tse, T. K.; Wong, K. A.; Wong, K. F. 2005. The utilisation of building information models in $\mathrm{nD}$ modelling: a study of data interfacing and adoption barriers, Journal of Information Technology in Construction (ITcon) 10 : 85-110.

Turkan, Y.; Bosche, F.; Haas, C. T.; Haas, R. 2012. Automated progress tracking using 4D schedule and 3D sensing technologies, Automation in Construction 22: 414-421. http://dx.doi.org/10.1016/j.autcon.2011.10.003

Underwood, J.; Isikdag, U. 2010. Handbook of research on building information modeling and construction informatics: concepts and technologies. IGI Global. 757 p.

Xiong, X.; Adan, A.; Akinci, B.; Huber, D. 2013. Automatic creation of semantically rich 3D building models from laser scanner data, Automation in Construction 31: 325337. http://dx.doi.org/10.1016/j.autcon.2012.10.006

Zhang, J. P.; Hu, Z. Z. 2011. BIM- and 4D-based integrated solution of analysis and management for conflicts and structural safety problems during construction: 1. Principles and methodologies, Automation in Construction 20(2): 155-166. http://dx.doi.org/10.1016/j.autcon.2010.09.013

Zhang, S.; Teizer, J.; Lee, J. K.; Eastman, C. M.; Venugopal, M. 2013. Building information modeling (BIM) and safety: automatic safety checking of construction models and schedules, Automation in Construction 29: 183-195. http://dx.doi.org/10.1016/j.autcon.2012.05.006

Zhou, Y.; Ding, L.Y.; Chen, L. J. 2013. Application of 4D visualization technology for safety management in metro construction, Automation in Construction 34: 25-36. http://dx.doi.org/10.1016/j.autcon.2012.10.011

Hui-Ping TSERNG. Full Professor at the Department of Civil Engineering of National Taiwan University. He also is corresponding member of Russian Academy of Engineering. He has a PhD in Construction Engineering and Management and he is official reviewer or editorial of board member of several international journals. His research interests include advanced techniques for knowledge management, construction project management, management information system, GPS/Wireless Sensor Network, and automation in construction.

Shih-Ping HO. Associate Professor of Construction Management at National Taiwan University. He taught at Stanford University in 2010 as endowed Shimizu Visiting Associate Professor. He is on the Editorial Board of Engineering Project Organization Journal. His research focuses on game theory modeling and analysis, the internationalization of $\mathrm{A} / \mathrm{E} / \mathrm{C}$ firms, the governance of Public-Private Partnerships (PPPs), strategic management, and knowledge sharing.

Shu-Hui JAN. PhD candidate of the Department of Civil Engineering of National Taiwan University. Her research deals with development and application of building information modeling (BIM) in AEC industry. Her research interests also include project management, construction management, information management, schedule management and property management. 